Short Communication

\title{
Genetic analysis reveals candidate species in the Scinax catharinae clade (Amphibia: Anura) from Central Brazil
}

Lídia Nogueira $^{1}$, Mirco Solé ${ }^{2}$, Sérgio Siqueira ${ }^{3}$, Paulo Roberto Antunes de Mello Affonso ${ }^{3}$, Christine Strüssmann ${ }^{4}$ and Iracilda Sampaio ${ }^{5}$

${ }^{1}$ Instituto Federal de Educação, Ciência e Tecnologia, Valença, BA, Brazil.

${ }^{2}$ Departamento de Ciências Biológicas, Universidade Estadual de Santa Cruz, Ilhéus, BA, Brazil.

${ }^{3}$ Departamento de Ciências Biológicas, Universidade Estadual do Sudoeste da Bahia, Jequié, BA, Brazil.

${ }^{4}$ Departamento de Ciências Básicas e Produção Animal, Universidade Federal de Mato Grosso, Cuiabá, MT, Brazil.

${ }^{5}$ Instituto de Estudos Costeiros, Universidade Federal do Pará, Bragança, PA, Brazil.

\begin{abstract}
Scinax (Anura: Hylidae) is a species-rich genus of amphibians (113 spp.), divided into five species groups by morphological features. Cladistic analyses however revealed only two monophyletic clades in these groups: Scinax catharinae and Scinax ruber. Most species from the $S$. catharinae clade are found in Atlantic rainforest, except for Scinax canastrensis, S. centralis, S. luizotavioi, S. machadoi, S. pombali and S. skaios. In the present work, specimens of Scinax collected in Chapada dos Guimarães, central Brazil, were morphologically compatible with species from the $S$. catharinae group. On the other hand, genetic analysis based on mitochondrial (16S and $12 S$ ) and nuclear (rhodopsin) sequences revealed a nucleotide divergence of 6 to $20 \%$ between Scinax sp. and other congeners from the Brazilian savannah (Cerrado). Accordingly, Bayesian inference placed Scinax sp. in the S. catharinae clade with high support values. Hence, these findings strongly indicate the presence of a new species in the $S$. catharinae clade from the southwestern portion of the Brazilian savannah. To be properly validated as a novel species, detailed comparative morphological and bioacustic studies with other taxa from Brazil such as $S$. canastrensis, S. centralis, S. luizotavioi, S. machadoi, S. pombali and S. skaios are required.
\end{abstract}

Keywords: Amphibians, DNA barcode, Cerrado, rDNA.

Received: February 06, 2014; Accepted: August 24, 2015.

The genus Scinax encompasses 113 species with a widespread distribution from southern Mexico to Argentina, Uruguay, St. Lucia and Trinidad and Tobago islands (Frost, 2015). Duellman and Wiens (1992) recognized seven species groups in this genus by means of morphological analyses (S. catharinae, S. perpusillus, S. rizibilis, $S$. rostratus, S. ruber, S. staufferi and S. x-signatus). Later, the groups S. rizibilis and $S$. $x$-signatus were regarded as synonyms of S. catharinae and S. ruber, respectively (Pombal et al., 1995a). Cladistic inferences however recovered only two monophyletic clades: S. catharinae (including the groups $S$. catharinae, $S$. staufferi and $S$. perpusillus) and $S$. ruber (encompassing the groups $S$. rostratus, S. ruber and some species within S. staufferi) (Faivovich, 2002; Faivovich et al., 2005).

Send correspondence to Lídia Nogueira. Instituto Federal de Educação, Ciência e Tecnologia, Rua Vereador Romeu Agrário Martins, s/n, Tento, CEP: 45400-000 - Valença -Bahia Brazil. E-mail: lidia.nogueira@yahoo.com.br
The $S$. catharinae group (Frost, 2015) is characterized by the lack of an anterior process in the suprascapula, $m$. depressor mandibulae without an origin at the dorsal fascia of the $m$. dorsalis scapulae, distal division of the middle branch of the $m$. extensor digitorum comunis longus, and insertion of this muscle at the medial side on the tendon of the $m$. extensor brevis medius digiti IV (Faivovich, 2002). The vocalization of frogs from this group is usually composed of short notes and, sometimes, displays harmonic structure (Pombal et al., 1995a, b).

Most species in this group are distributed throughout the Atlantic rainforest (Faivovich et al., 2005). The only exceptions reported so far include $S$. canastrensis, $S$. centralis, S. luizotavioi, S. machadoi, S. pombali and $S$. skaios, which were observed in gallery forests within the Brazilian savannah (Cerrado) and in central and southeastern Brazil (Pombal and Bastos, 1996; Pombal et al., 2010; Lourenço et al., 2013).

During inventories of herpetofauna carried out for the Management Plan of Chapada dos Guimarães National 
Park in the southwestern Cerrado, some samples of Scinax morphologically compatible with species of $S$. catharinae group were collected, but these specimens were differentiated from all other species described so far. Therefore, the goal of the present study was to perform a molecular analysis of these samples as an additional tool to their taxonomic identification, besides verifying the presence of a putative new representative in the $S$. catharinae clade in areas distant from their center of origin.

Eight individuals of Scinax sp. were collected on April 04, 2006 in deep gallery forests alongside headwaters of the Coxipó River, in Chapada dos Guimarães, state of Mato Grosso, Brazil (Figure 1, Table 1). The specimens were deposited in the Vertebrate Collection of the Universidade Federal de Mato Grosso (UFMT). Approximately $25 \mathrm{mg}$ of muscle were removed from the inner thigh of each specimen and preserved in ethanol $95 \%$ at $-20^{\circ} \mathrm{C}$ for molecular analyses.

Total DNA was extracted by using the Wizard $\AA$ Genomic Purification kit (Promega), following manufacturer's instructions. The primer pairs used to amplify $16 \mathrm{~S}$, 12S, and rhodopsin, respectively, were: L1- 5'GCCTCGC TTGTTTACCAAAAAC '3 (Palumbi, 1996) and H1 5'CCGGTCTGAACTCAGATCACGT 3' (Varela et al.,

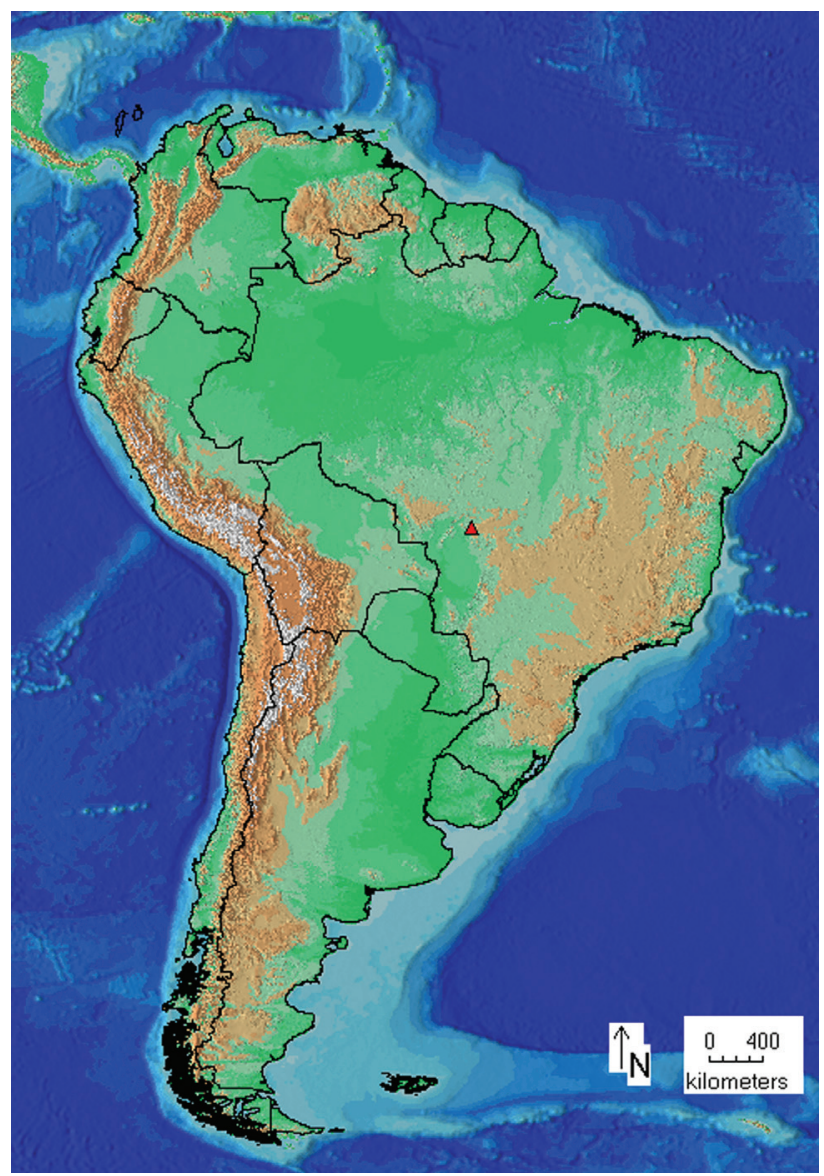

Figure 1 - Map of Brazil showing the collection sites of Scinax sp. in Chapada dos Guimarães, Mato Grosso, Brazil (red triangle).

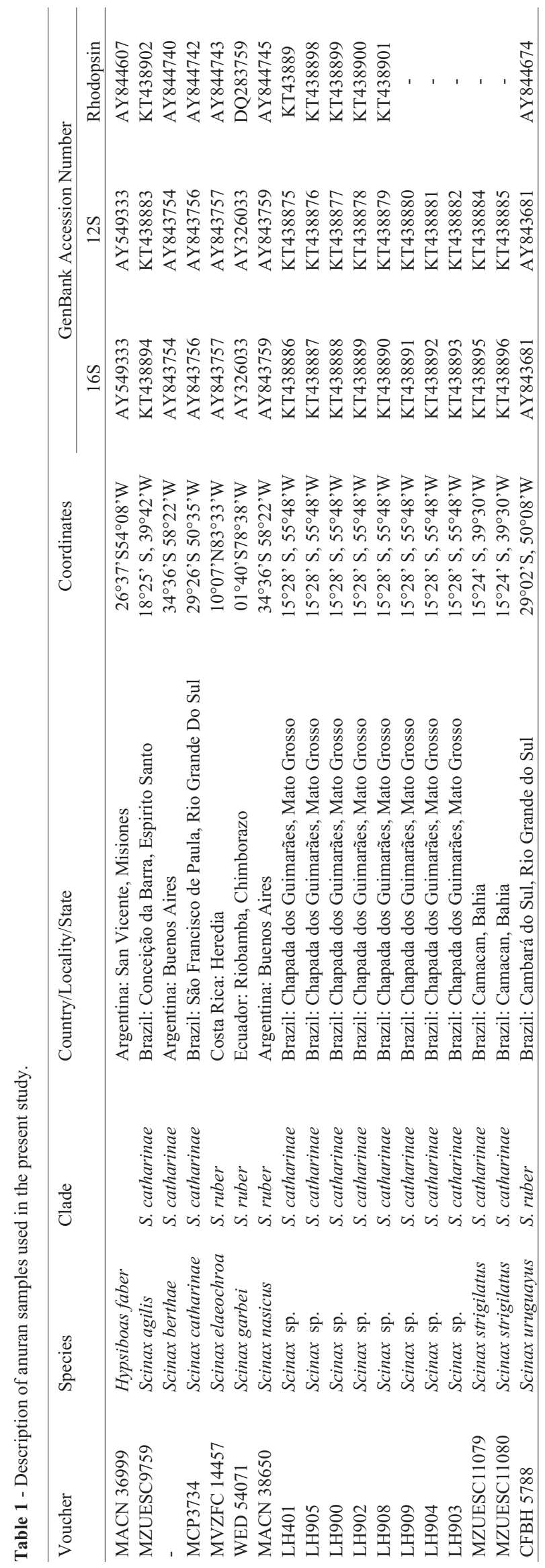


2007); L1- 5'AAAAAGCTTCAAACTGGGATTAGAT ACCCCACTAT 3' and H1- 5'TGACTGCAGAGGGTGA CGGGCGGTGTGT3' (Kocher et al., 1989), and Rhod-L1 5'ACCATGAACGGAACAGAAGGYCC 3' and RhodH1 5'GTAGCGAAGAARCTTCAAMGTA 3' (Bossuyt and Milinkovitch, 2000).

The PCR conditions consisted of an initial denaturation step at $95^{\circ} \mathrm{C}$ for $5 \mathrm{~min}$, followed by 35 cycles of denaturation at $94{ }^{\circ} \mathrm{C}$ for $40 \mathrm{~s}$, annealing at $55^{\circ} \mathrm{C}(12 \mathrm{~S}$ and $16 \mathrm{~S})$ or $49^{\circ} \mathrm{C}$ (rhodopsin) for $40 \mathrm{~s}$ and extension at $72{ }^{\circ} \mathrm{C}$ for 30 $\mathrm{s}$, plus a final extension step at $72{ }^{\circ} \mathrm{C}$ for $7 \mathrm{~min}$. Subsequently, the reaction products were purified and sequenced in an ABI 3500XL Genetic Analyzer automatic sequencer (Applied Biosystems). Sequencing reactions were carried out by using terminal dideoxynucleotides (Sanger et al., 1977). The sequences were then aligned with Clustal W available in the software BioEdit v. 5.09 (Hall, 1999). The software GBlocks 0.91 (Castresana, 2000) was used to eliminate poorly aligned positions and divergent region portions of $16 \mathrm{~S}$, according to the following parameters: minimum number of sequences for a flank position to 10 , maximum number of contiguous nonconserved positions to 08 , minimum length of a block to 2 , and allowed gap positions to within half.
To estimate the divergence matrix and phylogeny we added sequences of seven other anuran species from GenBank to our data set: S. catharinae, Scinax berthae, Scinax uruguayus, Scinax garbei, Scinax elaechroa, Scinax nasicus and Hypsiboas faber (outgroup). Two other species from the $S$. catharinae clade collected in Bahia, northeastern Brazil and Espirito Santo, southeastern Brazil, were also included in our analysis: Scinax strigilatus and Scinax agilis (Table 1).

Genetic divergence was estimated using the Kimura2-parameter (K2P) substitution model (Kimura, 1980) in the software MEGA v. 5.0 (Tamura et al., 2011). The 16S, $12 \mathrm{~S}$ and rhodopsin sequences were concatenated in the software DnaSP, v. 4.0 (Librado and Rozas, 2009).

A Bayesian phylogeny was inferred using the software MrBayes 3.1 (Ronquist and Huelsenbeck, 2003). The best mutation model was estimated according to Akaike Information Criteria - AIC in the software jModel Test 0.1 (Posada, 2008). Two runs (four chains each) with 20 million generations were performed with trees being sampled at every 1000 generations. Adequate burn-in was determined by examining likelihood scores of the heated chains for convergence on stationarity, as well as the effective sample size of values in Tracer 1.5 (Rambaut and Drum-

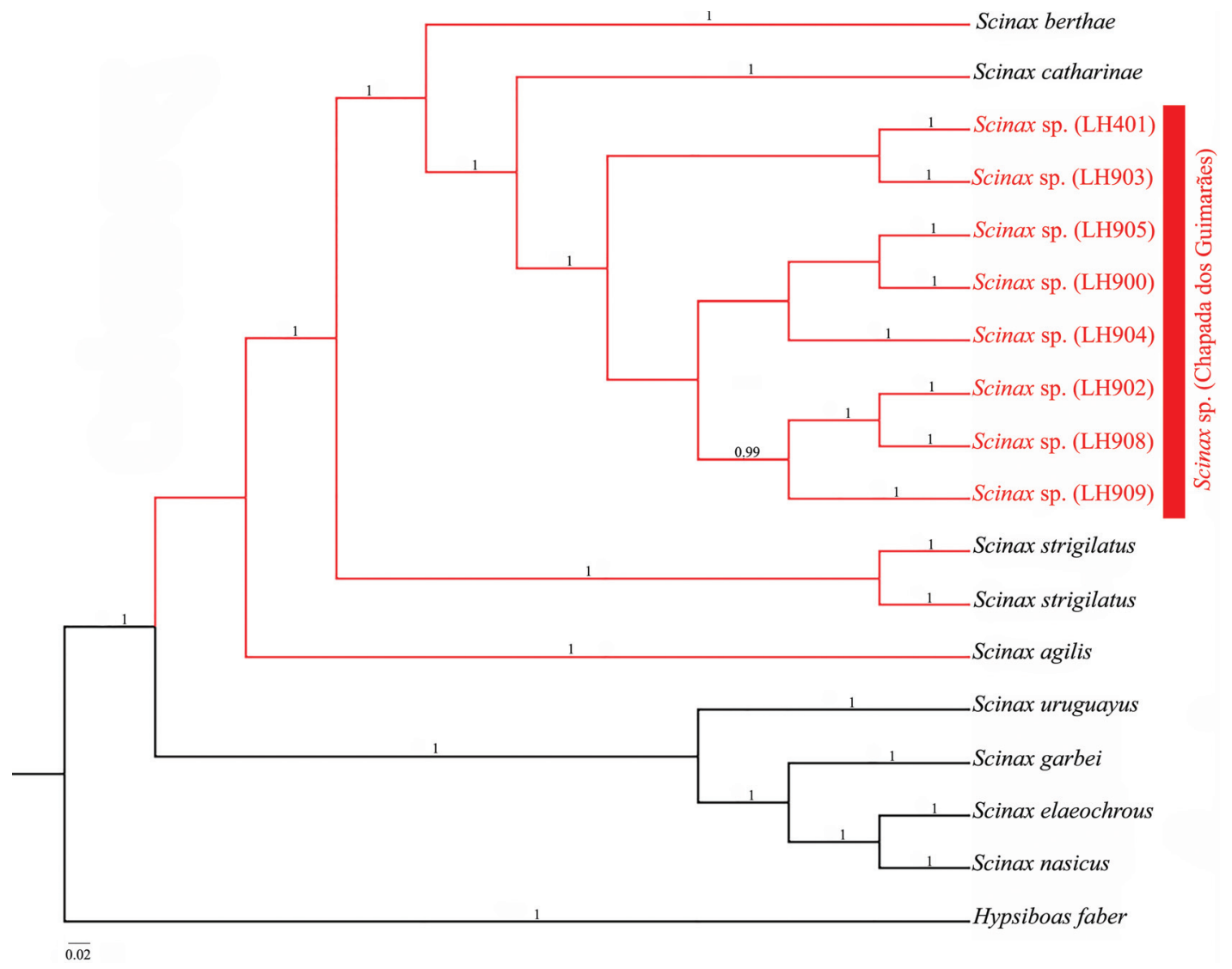

Figure 2 - Bayesian consensus phylogeny based on combined analysis of 12S, $16 \mathrm{~S}$ and rhodopsin (1,123 bp) of Scinax species, using $H$. faber as outgroup. Posterior probabilities higher than 0.95 are shown. The $S$. catharinae clade is highlighted in red while the $S$. ruber clade is highlighted in black. Scinax sp. (Chapada dos Guimarães, Mato Grosso, Brazil) corresponds to the specimens collected in this study. 
Table 2 - Interspecific nucleotide divergence within Scinax (Anura: Hylidae) based on K2P model of 16S (above diagonal), combined 12S+16S (above diagonal in parentheses), $12 \mathrm{~S}$ (below diagonal) and Rhodopsin (below diagonal in parentheses) genes. The species 1 to 5 belong to the $S$. catharinae clade, while the species 6 to 9 belong to the $S$. ruber clade; H. faber (10) was used as outgroup.

\begin{tabular}{|c|c|c|c|c|c|c|c|c|c|c|c|}
\hline & Species & 1 & 2 & 3 & 4 & 5 & 6 & 7 & 8 & 9 & 10 \\
\hline \multirow[t]{5}{*}{ S. catharinae clade } & 1. S. agilis & - & $\begin{array}{c}0.10 \\
(0.05)\end{array}$ & $\begin{array}{c}0.11 \\
(0.06)\end{array}$ & $\begin{array}{c}0.10 \\
(0.06)\end{array}$ & 0.10 & $\begin{array}{c}0.12 \\
(0.06)\end{array}$ & $\begin{array}{c}0.13 \\
(0.03)\end{array}$ & $\begin{array}{c}0.19 \\
(0.05)\end{array}$ & $\begin{array}{c}0.18 \\
(0.04)\end{array}$ & $\begin{array}{c}0.16 \\
(0.05)\end{array}$ \\
\hline & 2. S. berthae & $\begin{array}{c}0.10 \\
(0.10)\end{array}$ & - & $\begin{array}{c}0.05 \\
(0.03)\end{array}$ & $\begin{array}{c}0.06 \\
(0.03)\end{array}$ & 0.05 & $\begin{array}{c}0.10 \\
(0.06)\end{array}$ & $\begin{array}{c}0.12 \\
(0.04)\end{array}$ & $\begin{array}{c}0.17 \\
(0.04)\end{array}$ & $\begin{array}{c}0.15 \\
(0.06)\end{array}$ & $\begin{array}{c}0.15 \\
(0.06)\end{array}$ \\
\hline & 3. S. catharinae & $\begin{array}{c}0.10 \\
(0.10)\end{array}$ & $\begin{array}{c}0.04 \\
(0.04)\end{array}$ & - & $\begin{array}{c}0.05 \\
(0.01)\end{array}$ & 0.06 & $\begin{array}{c}0.10 \\
(0.06)\end{array}$ & $\begin{array}{c}0.12 \\
(0.05)\end{array}$ & $\begin{array}{c}0.18 \\
(0.06)\end{array}$ & $\begin{array}{c}0.14 \\
(0.07)\end{array}$ & $\begin{array}{c}0.15 \\
(0.05)\end{array}$ \\
\hline & 4. Scinax sp. & $\begin{array}{c}0.10 \\
(0.10)\end{array}$ & $\begin{array}{c}0.06 \\
(0.06)\end{array}$ & $\begin{array}{c}0.06 \\
(0.05)\end{array}$ & - & 0.07 & $\begin{array}{c}0.12 \\
(0.05)\end{array}$ & $\begin{array}{c}0.15 \\
(0.04)\end{array}$ & $\begin{array}{c}0.21 \\
(0.05)\end{array}$ & $\begin{array}{c}0.16 \\
(0.06)\end{array}$ & $\begin{array}{c}0.15 \\
(0.04)\end{array}$ \\
\hline & 5. S. strigilatus & $\begin{array}{c}0.10 \\
(0.10)\end{array}$ & $\begin{array}{c}0.06 \\
(0.06)\end{array}$ & $\begin{array}{c}0.06 \\
(0.06)\end{array}$ & $\begin{array}{c}0.07 \\
(0.07)\end{array}$ & - & 0.10 & 0.13 & 0.17 & 0.15 & 0.16 \\
\hline \multirow[t]{5}{*}{ S.ruber clade } & 6. S. uruguayus & $\begin{array}{c}0.15 \\
(0.13)\end{array}$ & $\begin{array}{c}0.13 \\
(0.12)\end{array}$ & $\begin{array}{c}0.12 \\
(0.11)\end{array}$ & $\begin{array}{c}0.11 \\
(0.11)\end{array}$ & $\begin{array}{c}0.12 \\
(0.11)\end{array}$ & - & $\begin{array}{c}0.10 \\
(0.02)\end{array}$ & $\begin{array}{c}0.17 \\
(0.03)\end{array}$ & $\begin{array}{c}0.13 \\
(0.04)\end{array}$ & $\begin{array}{c}0.15 \\
(0.05)\end{array}$ \\
\hline & 7. S. elaeochrous & $\begin{array}{c}0.13 \\
(0.13)\end{array}$ & $\begin{array}{c}0.13 \\
(0.12)\end{array}$ & $\begin{array}{c}0.13 \\
(0.12)\end{array}$ & $\begin{array}{c}0.13 \\
(0.13)\end{array}$ & $\begin{array}{c}0.12 \\
(0.12)\end{array}$ & $\begin{array}{c}0.11 \\
(0.10)\end{array}$ & - & $\begin{array}{c}0.16 \\
(0.01)\end{array}$ & $\begin{array}{c}0.12 \\
(0.02)\end{array}$ & $\begin{array}{c}0.15 \\
(0.04)\end{array}$ \\
\hline & 8. S. nasicus & $\begin{array}{c}0.12 \\
(0.15)\end{array}$ & $\begin{array}{c}0.13 \\
(0.14)\end{array}$ & $\begin{array}{c}0.13 \\
(0.15)\end{array}$ & $\begin{array}{c}0.13 \\
(0.16)\end{array}$ & $\begin{array}{c}0.12 \\
(0.14)\end{array}$ & $\begin{array}{c}0.14 \\
(0.15)\end{array}$ & $\begin{array}{c}0.07 \\
(0.11)\end{array}$ & - & $\begin{array}{c}0.16 \\
(0.03)\end{array}$ & $\begin{array}{c}0.21 \\
(0.06)\end{array}$ \\
\hline & 9. S. garbei & $\begin{array}{c}0.14 \\
(0.15)\end{array}$ & $\begin{array}{c}0.13 \\
(0.14)\end{array}$ & $\begin{array}{c}0.14 \\
(0.14)\end{array}$ & $\begin{array}{c}0.12 \\
(0.13)\end{array}$ & $\begin{array}{c}0.13 \\
(0.14)\end{array}$ & $\begin{array}{c}0.11 \\
(0.11)\end{array}$ & $\begin{array}{c}0.10 \\
(0.10)\end{array}$ & $\begin{array}{c}0.13 \\
(0.14)\end{array}$ & - & $\begin{array}{c}0.20 \\
(0.05)\end{array}$ \\
\hline & 10. Outgroup & $\begin{array}{c}0.16 \\
(0.16)\end{array}$ & $\begin{array}{c}0.15 \\
(0.15)\end{array}$ & $\begin{array}{c}0.15 \\
(0.15)\end{array}$ & $\begin{array}{c}0.15 \\
(0.15)\end{array}$ & $\begin{array}{c}0.16 \\
(0.16)\end{array}$ & $\begin{array}{c}0.17 \\
(0.16)\end{array}$ & $\begin{array}{c}0.14 \\
(0.15)\end{array}$ & $\begin{array}{c}0.16 \\
(0.18)\end{array}$ & $\begin{array}{c}0.15 \\
(0.17)\end{array}$ & - \\
\hline
\end{tabular}

mond, 2007). We discarded $10 \%$ of the generations/trees. We considered relationships strongly supported when posterior probabilities were equal to or higher than 0.95 .

Eighteen sequences of $16 \mathrm{~S}$ and $12 \mathrm{~S}$ were obtained from each of the nine Scinax species, comprising $423 \mathrm{bp}$ (164 variable sites) and 386 bp (131 variable sites) for each fragment respectively. For rhodopsin, 13 sequences of $316 \mathrm{bp}$ with 51 variable sites were obtained from eight Scinax representatives.

The intraspecific nucleotide divergence in Scinax sp. was $0.2 \%$ for $16 \mathrm{~S}, 0.3 \%$ for $12 \mathrm{~S}, 0.2 \%$ for combined $12 \mathrm{~S}+16 \mathrm{~S}$, and $0 \%$ for the rhodopsin. The nucleotide divergence of Scinax sp. in relation to the other species ranged from 6 to $13 \%, 7$ to $20 \%, 6$ to $18 \%$ and 0.6 to $6 \%$ for $16 \mathrm{~S}$, $12 \mathrm{~S}, 16 \mathrm{~S}+12 \mathrm{~S}$ and rhodopsin, respectively (Table 2).

The Bayesian consensus phylogeny $(16 \mathrm{~S}+12 \mathrm{~S}+$ rhodopsin) placed Scinax sp. as a distinct clade with strong support, being closely related to $S$. berthae, $S$. catharinae, $S$. strigilatus and $S$. agilis, all belonging to the $S$. catharinae clade (Figure 2 and Table 2). The four species from the $S$. ruber clade also formed a monophyletic group with strong support.

Even though the cytochrome $\mathrm{C}$ oxidase I (COI) gene has been elected as a universal DNA barcode in animals (Hebert et al., 2003), the 16S gene seems to be more effective to discriminate amphibian species (Vences et al., 2005), thus being used in the present study. Indeed, the genetic distances of 7 to $10 \%$ in $16 \mathrm{~S}$ rDNA observed between Scinax sp. and the other known species in the $S$. catharinae clade (S. berthae, S. catharinae, S. strigilatus and S. agilis)
(Table 2) are higher than the minimum value of 3\% in nucleotide divergence proposed by Fouquet et al. (2007) to discriminate anuran species. Moreover, sequences of $12 \mathrm{~S}$ and rhodopsin (nuclear) were also included to provide additional support to our hypothesis of a new species in the $S$. catharinae clade occuring in the Chapada dos Guimarães.

Many researchers advocate the integration of multiple approaches (molecular, cytogenetic, morphological and ecological studies) for identifying species (Dayrat, 2005; Padial et al., 2010). According to the nomenclature rules established by Vieites et al. (2009), Scinax sp. could be classified as an "unconfirmed candidate species" (UCS), depending on additional morphological, ecological and vocalization studies to confirm its taxonomic status.

In conclusion, our molecular data provide evidence of a new species in the $S$. catharinae clade occurring in the Chapada dos Guimarães region, central Brazil. However, further morphological and bioacoustical analyses should be performed and focused on comparative data with other species from the $S$. catharine clade from Brazilian savannah, such as $S$. canastrensis, S. centralis, S. luizotavioi, $S$. machadoi, S. pombali and S. skaios.

\section{Acknowledgments}

The authors are grateful to CAPES and CNPq for the financial support and the Brazilian Environmental Agency ICMBio for the logistic support during field trips. The biological material was collected with permission of IBAMA (license 223/2005 from Sept. 14, 2005). CS, IS and MS 
thank CNPq for research fellowships (Bolsa de Produtividade em Pesquisa; processes \# 309541/2012-3, \# 306416/2013-1 and \# 307165/2012-4).

\section{References}

Bossuyt F and Milinkovitch MC (2000) Convergent adaptive radiations in Madagascan and Asian ranid frogs reveal covariation between larval and adult traits. Proc Natl Acad Sci USA 976585-6590.

Castresana J (2000) Selection of conserved blocks from multiple alignments for their use in phylogenetic analysis. Mol Biol Evol 17:540-552.

Dayrat B (2005) Integrative taxonomy. Biol J Linn Soc 85:407415.

Duellman WE and Wiens JJ (1992) The status of the hylid frog genus Ololygon and the recognition of Scinax Wagler, 1830. Occas. Pap Mus Nat Hist Univ Kansas151:1-23.

Faivovich J (2002) A cladistic analysis of Scinax (Anura:Hylidae). Cladistics 18:367-393.

Faivovich J, Haddad CFB, Garcia PC, Frost DR, Campbell JA and Wheeler WC (2005) Systematic review of the frog family Hylidae, with special reference to Hylinae: phylogenetic analysis and taxonomic revision. Bull Am Mus Nat Hist 294:6-229.

Fouquet A, Gilles A, Vences M and Marty C (2007) Underestimation of species richness in Neotropical frogs revealed by mtDNA analyses. PLoS One 10: e1109.

Hall TA (1999) BioEdit: a user-friendly biological sequence alignment editor and analysis program for Windows 95/98/NT. Nucleic Acids. Symp Ser 41:95-98.

Hebert PDN, Cywinska A, Ball SL and Waard JR (2003) Biological identifications through DNA barcodes. Proc R Soc Lond 270:313-321.

Kimura M (1980) A simple method for estimating evolutionary rates of base substitutions through comparative studies of nucleotide sequences. J Mol Evol 16:111-120.

Kocher TD, Thomas WK, Meyer A, Edwards SV, Pääbo S, Villablanca FX and Wilson AC (1989) Dymamics of mitochondrial DNA evolution in animals: amplification and sequencing with conserved primers. Proc Natl Acad Sci USA 86:6196-6200.

Librado P and Rozas J (2009) DnaSP v5: A software for comprehensive analysis of DNA polymorphism data. Bioinformatics 25:1451-1452.

Lourenço ACC, Carvalho ALG, Baêta D, Pezzuti TL and Leite FSF (2013) A new species of the Scinax catharinae group (Anura, Hylidae) from Serra da Canastra, southwestern state of Minas Gerais, Brazil. Zootaxa 3613:573-588.

Padial JM, Miralles AD, De la Riva I and Vences M (2010) The integrative future of taxonomy. Front Zool 7:1-14.

Palumbi SR (1996) Nucleic acids II: The polymerase chain reaction. In: Hillis DM, Moritz C and Mable BK (eds) Molecular systematics. Sinauer Associates, Inc, Sunderland, MA, pp 205-247.

Pombal JJ and Bastos RP (1996) Nova espécie de Scinax Wagler, 1830 do Brasil Central (Amphibia, Anura, Hylidae). Bol Mus Nac 371:1-11.

Pombal JJ, Haddad CFB and Kasahara S (1995a) A new species of Scinax (Anura: Hylidae) from southeastern Brazil, with comments on the genus. J Herpetol 29:1-6.

Pombal JJ, Bastos RP and Haddad CFB (1995b) Vocalizações de algumas espécies do gênero Scinax (Anura, Hylidae) do sudeste do Brasil e comentários taxonômicos. Naturalia 20:213-225.

Pombal JJ, Carvalho RRJ, Canelas MAS and Bastos RP (2010) A new Scinax of the $S$. catharinae species group from Central Brazil (Amphibia: Anura: Hylidae). Zoologia 27:795-802.

Posada D (2008) jModelTest: Phylogenetic Model Averaging. Mol Biol Evol 25:1253-1256.

Ronquist F and Huelsenbeck JP (2003) MrBayes 3: Bayesian phylogenetic inference under mixed models. Bioinformatics 19:1572-1574.

Sanger F, Nicklen S and Coulson AR (1977) DNA sequencing with chain-terminating inhibitors. Proc Natl Acad Sci USA 12:5463-5467.

Tamura K, Peterson D, Peterson N, Stecher G, Nei M and Kumar S (2011) MEGA5: Molecular Evolutionary Genetics Analysis using Maximum Likelihood, Evolutionary Distance, and Maximum Parsimony methods. Mol Biol Evol 28:27312739.

Varela ES, Beasley CR, Schneider H, Sampaio I, Marques-Silva NS and Tagliaro CH (2007) Molecular phylogeny of mangrove oysters (Crassostrea) from Brazil. J Molluscan Stud 73:229-234.

Vences M, Thomas M, Bonett RM and Vieites DR (2005) Deciphering amphibian diversity through DNA barcoding: chances and challenges. Phil Trans R Soc B 360:1859-1868.

Vieites DR, Wollenberg KC, Andreone F, Köhler J, Glaw F and Vences M (2009) Vast underestimation of Madagascar's biodiversity evidenced by an integrative amphibian inventory. Proc Natl Acad Sci USA 106:8267-8272.

\section{Internet Resources}

Frost DR (2015) Amphibian Species of the World: An Online Reference. Version 6.0. American Museum of Natural History, New York, USA. http://research.amnh.org/herpetology/amphibia/index.html (accessed July 27, 2015).

Rambaut A and Drummond A (2007) TRACER. MCMC Trace Analysis Tool, Version 1.4. University of Oxford. http://tree.bio.ed.ac.uk/software/tracer.

\section{Associate Editor: Antonio Mateo Solé}

License information: This is an open-access article distributed under the terms of the Creative Commons Attribution License (type CC-BY), which permits unrestricted use, distribution and reproduction in any medium, provided the original article is properly cited. 